\title{
Correction to: BMIPP SPECT in cardiac sarcoidosis: A marker of risk?
}

\author{
Roxana Campisi, MD, ${ }^{\mathrm{a}, \mathrm{b}}$ María Fernanda Merani, $M D,{ }^{\mathrm{a}, \mathrm{b}}$ and \\ Marina I. Rodríguez, $\mathrm{MD}^{\mathrm{a}}$ \\ a Departments of Nuclear Medicine and Cardiovascular Imaging, Diagnóstico Maipú, Buenos \\ Aires, Argentina \\ b Department of Nuclear Medicine, Instituto Argentino de Diagnóstico y Tratamiento S.A, \\ Buenos Aires, Argentina
}

doi: 10.1007/s12350-021-02669-9

\section{CORRECTION TO: JOURNAL OF NUCLEAR CARDIOLOGY HTTPS://DOI.ORG/10.1007/S1 2350-021-02626-6}

Please note the corrections in Table 1. The first column (third cell) should read "scan interpretation" and not "scan". Fourth cell should be empty instead of reading "scan with absence of active".

Second column, third cell should read "normal", and not "interpretation". Fourth cell: "inflammation", should be deleted.
Third column, third cell should read "inflammation and no scar (early disease)" and not" normal".

Fourth column, third cell should read "scar and inflammation (mismatch pattern)', and not "inflammation and no scar (early disease)',

Fifth column, third cell should read "scar with absence of active inflammation", and not"scar and inflammation (mismatch pattern)', The correct Table 1 is given here.

The original article has been corrected.

Table 1. Myocardial perfusion and ${ }^{18} \mathrm{~F}$ - FDG PET imaging patterns for cardiac sarcoidosis

\begin{tabular}{|c|c|c|c|c|}
\hline $\begin{array}{l}\text { Myocardial } \\
\text { perfusion }\end{array}$ & Normal & Normal & Abnormal & Abnormal \\
\hline${ }^{18} \mathrm{~F}-\mathrm{FDG}$ uptake & $\begin{array}{l}\text { No uptake } \\
\text { Diffuse/lateral wall } \\
\text { uptake (non-specific } \\
\text { pattern) }\end{array}$ & Focal increase & $\begin{array}{l}\text { Focal increase } \\
\text { (different areas) }\end{array}$ & No uptake \\
\hline $\begin{array}{l}\text { Scan } \\
\text { interpretation }\end{array}$ & Normal & $\begin{array}{l}\text { Inflammation and no } \\
\text { scar (Early Disease) }\end{array}$ & $\begin{array}{l}\text { Scar and } \\
\text { inflammation } \\
\text { (Mismatch Pattern) }\end{array}$ & $\begin{array}{l}\text { Scar with absence of } \\
\text { active } \\
\text { inflammation }\end{array}$ \\
\hline
\end{tabular}

Adapted from Wiefels et al. ${ }^{3}$ and Blankstein et al. ${ }^{6}$

${ }_{18}$ F-FDG, ${ }^{18}$ F-Fluorodeoxyglucose; $P E T$, positron emission tomography

The original article can be found online at https://doi.org/10.1007/ s12350-021-02626-6.

Reprint requests: Roxana Campisi, MD, Departments of Nuclear Medicine and Cardiovascular Imaging, Diagnóstico Maipú, Diagnóstico Maipú, Av. Maipú 1668, Vicente López (B1602ABQ), Buenos Aires, Argentina; roxanacampisi@yahoo.com

J Nucl Cardiol 2021;28:1760.

$1071-3581 / \$ 34.00$

Copyright (C) 2021 American Society of Nuclear Cardiology.
Publisher's Note Springer Nature remains neutral with regard to jurisdictional claims in published maps and institutional affiliations. 